Economía Agraria y Recursos Naturales. ISSN: 1578-0732. Vol. 6, 12. (2006). pp. 187-213

\title{
Impact of climate policy on the Basque economy
}

\author{
Mikel González a, ${ }^{\text {a }}$ Rob Dellink ${ }^{\mathrm{b}}$
}

SUMMARY: In this paper analyze the economic effects of $\mathrm{CO}_{2}$ emission reductions in the Basque Country (Spain) using an applied general equilibrium (AGE) model with specific attention to environment-energy-economy interactions. Environmental policy is implemented through a system of tradable pollution permits that the government auctions. The costs of different levels of $\mathrm{CO}_{2}$ abatement are discussed, focusing on the variations of macroeconomic, sectoral and environment-energy variables. Results show that the costs for achieving the Kyoto targets can remain limited if the appropriate combination of changes in fuel-mix and restructuring of the economy is induced.

KEYWORDS: Applied General Equilibrium. Climate change. Tradable pollution permits. Basque Country.

JEL classification: D58, H21, Q20, Q28.

\section{Impacto económico del control del cambio climático en el País Vasco}

RESUMEN: En este trabajo analizamos el impacto económico de una reducción de las emisiones de $\mathrm{CO}_{2}$ en el País Vasco. Para ello utilizamos un modelo de equilibrio general aplicado (MEGA), que presta

${ }^{a}$ Fundamentos del Análisis Económico I, Universidad del País Vasco, Bilbao, España.

${ }^{b}$ Institute for Environmental Studies, Vrije Universiteit, Amsterdam, The Netherlands and Environmental Economics and Natural Resources group, Wageningen University, Wageningen, The Netherlands.

* Corresponding author: University of Basque Country. Tel.: +34-94-6013784. Fax: +34-94-6013891.

E-mail address: mikel.gonzalez@ehu.es.

Mikel González is grateful to the Environmental Economics and Natural Resources Group (Wageningen University) and to Spanish Ministry of Education for financial support (FPU-ref.-2002-1001). 
especial atención a las interacciones entre economía, medio ambiente y energía y que implementa la política ambiental mediante un mercado de permisos de emisión regulado por el gobierno. El artículo discute el coste de reducción de diferentes niveles en las emisiones, mostrando las variaciones en las principales variables macroeconómicas, sectoriales y energéticas. Los resultados muestran que los costes de cumplir los objetivos de Kyoto pueden ser moderados, si se consiguen inducir los cambios apropiados en el mix energético y en las estructuras de producción y consumo.

PALABRAS CLAVE: Modelos de Equilibrio General Aplicado. Cambio Climático. Mercados de Permisos de Emisión. País Vasco.

Clasificación JEL: D58, H21, Q20, Q28..

\section{Introduction}

Scientists have extensively studied the relations between human actions, accumulation of greenhouse gases (GHGs) and climate change. One of the hottest topics on the environmental agenda in the second meeting of the Parties to the Kyoto Protocol (COP/MOP 2) Nairobi 2006) was to what extent global GHGs concentration should be reduced in the coming (Post-Kyoto) future and how to share this target between countries and regions. Projecting the cost of GHG reduction is crucial in taking rational and informed decisions in this negotiation process and, hence, an extensive literature has flourished around this matter (Springer, 2003; Weyant, 2004).

According to the Kyoto Protocol, Spain was allowed to increase their GHG emissions by $15 \%$ from 1990 levels by 2008-2012, but in 2005, they had increased up to $52 \%$, turning Spain into the European country that is most far away from reaching its objectives and implying that a substantial emission reduction will be required to achieve the Kyoto target.

So far, there are few studies concerning empirical estimation of these effects for Spain, and its regions. De Miguel et al. (2006) used an applied general equilibrium (AGE) model to study the impact of climate policy on Spain, and Manresa et al. (2004) studied the case of the Catalonia region in an input-output framework. These studies show that the costs of immediate and medium-size reductions are limited in the short run and they are optimistic about the cost of attaining Kyoto objectives.

The important differences in economic structure between the Spanish regions limits the extrapolation of Kyoto cost from the national to regional level. Although greenhouse gas abatement objectives are normally decided by national governments, insight into regional impacts is highly relevant for future state-level GHGs reduction negotiations. Moreover, it is important to know how these policies will affect different regions in order to develop their own energy and climate policy strategies and to carry out the best adaptative actions.

In this paper we aim to evaluate the impacts of Spanish climate policies on the Basque Country by analyzing the economics effects of $\mathrm{CO}_{2}$ emissions reduction in an AGE framework with specific attention to environment-energy-economy interactions. The instrument used to implement environmental policy is a tradable emission permit system. 
The Basque country is a region in Spain with a considerable level of autonomy to develop its own fiscal and energy policy. As far as climate change is concerned, the Basque country assumes national objectives but has the possibility to develop its own policy with taxes, regulations or industrial organization plans. Basque Country is a relatively high energy consuming region (7.5 Mtep in 2005), with $18 \%$ of total Spanish demand, representing a cost for final consumers of 3.5 million Euro. Of total energy demand, $50 \%$ is constituted by oil, $23 \%$ by gas and $6 \%$ by coal. Electricity represents a $14 \%$ of the total and renewable energies are still below 7\%. Most fossil fuels are imported from Spain and the Rest of the world as the amount of extraction of fossil fuels in the region is insignificant.

The article is organized as follows. In Section 2 we present the characteristics of the AGE model used in the analysis. Section 3 discusses the main results for the macro economy, sectoral composition, energy use and marginal abatement costs. In Section 4 we conduct a sensitivity analysis to assess the robustness of the model with respect to the main model parameters; and, finally, Section 5 contains some final remarks.

\section{Characteristics of the model}

\subsection{General description of AGE models}

The framework we use for our model is multi-sectoral, static, applied general equilibrium (AGE) modeling for a small open economy. AGEs are essentially numerical versions of the Arrow-Debreu general equilibrium structure, using real data. These models consider the fully closed economic cycle and are suitable when indirect effects for the policy to be analyzed are relevant. For a good introduction into AGE modelling see Ginsburgh \& Keyzer (1997) and Shoven \& Whalley (1992).

General equilibrium can be described by a set of economic agents, households and firms, that demand and supply different goods. AGE model results are the solution of a non-linear equations system where 1) zero profit, 2) income balance, and 3) market clearance conditions hold simultaneously and for all agents. According to neoclassical theory assumptions, agents behave rationally, take prices as given and solve their own optimization problem. Producers operate under full competition and maximize profit subject to current technology. Under constant returns to scale net profits are zero; the value of output has to equal the value of all inputs used (zero profit condition). Consumers have an initial endowment of factors and maximize utility subject to the budget constraint; the value of income must equal the total value of expenditures (income balance condition). Finally, equilibrium is characterized by a set of equilibrium prices such that demand equals supply for all commodities simultaneously (market clearance condition). In this situation agents cannot do better by altering their behaviour. The zero homogeneity of demand functions and the linear homogeneity of profits in prices imply that, in the general equilibrium context, only relative prices matter. Hence, a numéraire has to be chosen to fix the absolute price level; in our model this role is played by the consumer price index. 


\subsection{Description of the CGE model for the Basque country}

The economy is disaggregated in 27 sectors, including four energy sectors. Sectors and goods correspond: each sector produces one unique good and vice versa. apart from the energy carriers, we consider two other production factors; labor and capital. Private households are aggregated into a representative consumer; a government sector is specified that deals with taxes, consumption of public goods and implements environmental policy, and finally, trade takes place with two regions; Rest of Spain and Rest of the World. The general structure of the model is represented in figure 1 and the main elements are briefly described in the subsections below. The model is solved using GAMS/MPSGE (Rutherford, 1999) ${ }^{1}$ and a complete specification of the equations and notation can be found in Appendices.

\section{FIGURE 1}

General structure of the model

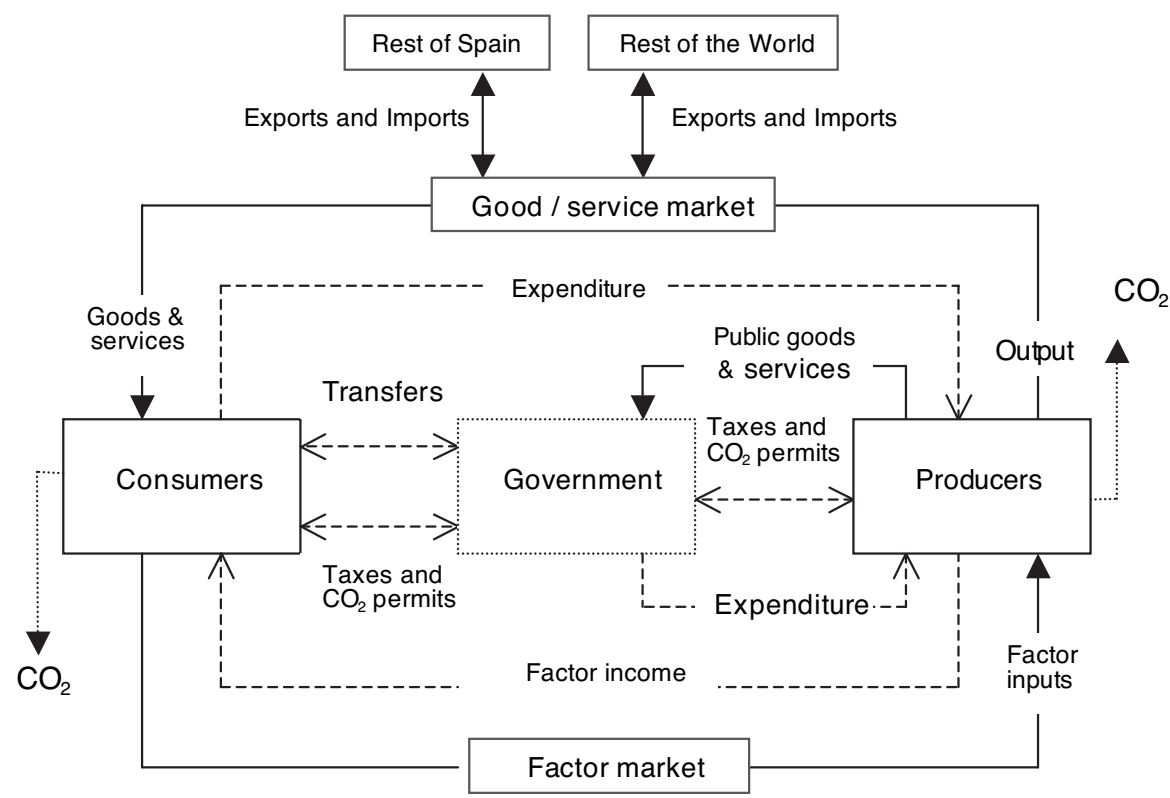

\subsubsection{Producers}

Producers maximize profits subject to a technology constraint (production function). They need intermediate inputs, labor, capital and $\mathrm{CO}_{2}$ emissions permits for their activity, and receive income from selling their products after paying the corresponding taxes.

\footnotetext{
${ }^{1}$ MPSGE is a programming tool that runs in GAMS platform and solves general equilibrium models in a mixed complementarity (MCP) format.
} 
In most AGE models technology and substitution possibilities are described by a nested production structure in which constant elasticity of substitution (CES) functions are hierarchically combined. This article assumes the same structure as in the GTAP-E model (Rutherford \& Paltsev, 2000) for the specification of the substitution possibilities between fossil fuels. $\mathrm{CO}_{2}$ emission permits are considered a necessary input in production and emissions are generated in fixed proportion to the use of coal, oil and gas.

The production structure is represented in figure 2. The parameter $(\sigma)$ represents the substitution elasticity to produce the composite between the inputs directly below, using a CES function ${ }^{2}$. Elasticities are the same for all sectors except in the case of the elasticity between Energy and Capital-Labor $\left(\sigma_{j}^{K E L}\right)$ and between Labor and Capital $\left(\sigma_{j}^{K L}\right)$, where sectoral differentiation is important. The values of all the elasticities can be found in Appendices.

FIGURE 2

CES Nested Production Structure

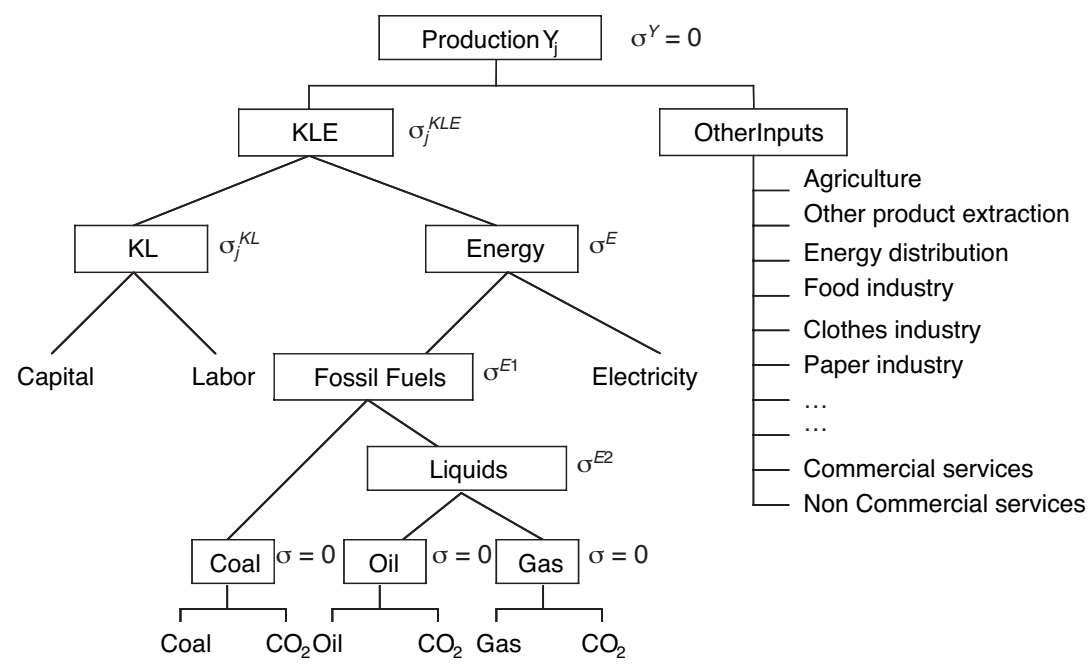

\subsubsection{International Trade}

International trade is modelled following two common assumptions. First, we adopt the «small open economy» assumption, meaning that (a) the domestic market is too small to influence world prices and (b) the world market can satisfy all the importing and exporting requirements of the domestic economy. Secondly, we adopt the «Armington assumption» (Armington, 1969) which considers domestic and foreign

\footnotetext{
${ }^{2}$ For instance, Capital and Labor can be mutually substituted with the elasticity $\sigma_{j}^{K L}$ to form the KL composite. Similarly, KL and Energy can be also substituted with the elasticity $\sigma_{j}^{K E L}$ to produce the KEL composite. In the case of emissions and $\mathrm{CO}_{2}$ permits a zero elasticity implies that for each unit of emissions a permit is required.
} 
goods as imperfect substitutes. This approach helps to explain the observed differences in domestic and foreign goods prices and, practically, avoids an outcome with full specialisation. This is implemented, as in the production functions, using a CES framework as illustrated in figure 2 .

As the policy simulated in the model is part of a national policy for Spain, it is natural to assume that there are no possibilities to substantially change the trading relations with the Rest of Spain. We implement this by adopting trade elasticities between Basque Country and Rest of Spain equal to zero. In contrast, there are possibilities to change trade patterns with the Rest of the World. This is incorporated by positive trade elasticities between the composite of Basque and Rest of Spain with the Rest of the World. The structure of trade function is represented in figure 2.

Finally it is necessary to specify a closure rule for economic flows. In this model, we consider the common assumption that the trade surplus, i.e. the excess of exports over imports, is financed by savings on the consumer's budget. Given that most trade from the Basque country is performed with other regions that have adopted the Euro currency, we adopt the (ad hoc) assumption that the trade deficit adjusts to clear the trade market while the exchange rate is constant.

FIGURE 3

\section{CES Nested Trade Structure}

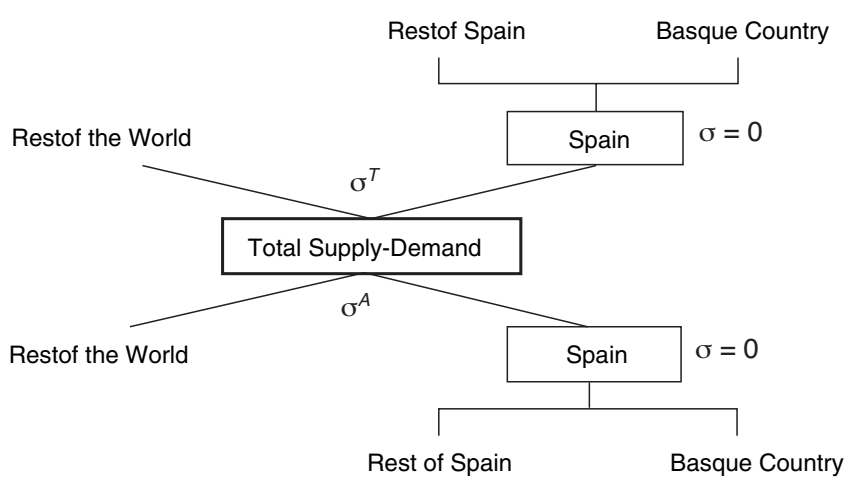

\subsubsection{Consumers}

We consider a representative consumer that maximizes utility subject to the budget constraint. Utility is formed in a CES function comprising a consumption bundle and leisure, as illustrated in figure 4 . The consumption composite is similarly formed with a CES function of energy and non-energy goods. Consumers get income from selling their endowments of labor and capital and from lump sum transfers from the government. They need to buy emission permits in fixed proportion to the use of fossil fuels ${ }^{3}$. Savings are used to finance investment and to cover the trade surplus.

\footnotetext{
3 Tradable permits may not be the best policy instrument for reducing consumer emissions in reality, but in our stylized framework without transaction costs, they function similar to taxation.
} 
FIGURE 4

CES Nested Utility Structure

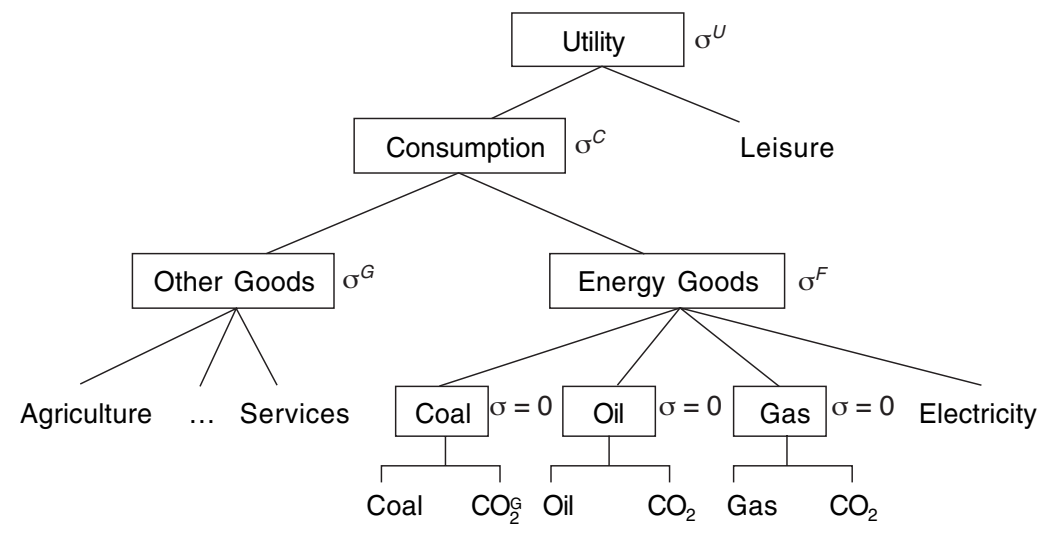

\subsubsection{Government}

The government collects taxes on production, labour and consumption, and auctions the emission permits. Revenues are spent on public consumption and transfers to the consumers so that the public deficit remains zero. We assume that any change in government income, due to the extra income received from the emission permits, is balanced with increasing lump sum transfers and, hence, the size of public consumption and public deficit remains constant. This implies that utility from public goods is constant and changes in utility only stem from changes in private consumption (equal-yield assumption). For simplicity we consider there are no explicit financial transfers between Basque and Spanish government and all relations go through the trade balance.

\subsubsection{Labour and Capital Supply}

Labour supply is endogenized using the labour-leisure choice in the utility function. The representative consumer is endowed with an exogenous amount of time to share between labor and leisure. More time dedicated to labour means more revenues to be used for consumption.

Another important feature concerns capital flows and the investment decision specification in a static AGE model. The level of investment in a real economy depends upon interest rates, depreciation, and on previous capital stock but, in a static context, this cannot be fully incorporated in the model. Therefore, we assume that consumers are endowed initially with a certain capital stock that adjusts following the condition that in equilibrium the price of investment should be equal to the rental price of capital delivered by that investment (cf. Hayashi, 1982). In this way, the investment decision is consistent with the return to capital in the counterfactual analysis. 


\subsection{Data and model calibration}

The model is calibrated using a social accounting matrix (SAM) for the Basque Country built from the I/O Tables (EUSTAT, 2000) and integrating energy demand information from the Energy Balances (EVE, 2000). In the calibration process, values are given to parameters such that the model can reproduce the SAM as an equilibrium solution. This replication represents the initial allocation of resources, the socalled benchmark equilibrium.

For a comparative static analysis we need data for the agents' responses to changes in circumstances. These reactions are given by elasticities and govern the transition to a new equilibrium solution or counterfactual equilibrium. We use data from a literature selection made for the Spanish economy by Gomez, Faehn, \& Kverndokk (2004) and from GTAP-E model (Rutherford \& Paltsev, 2000).

Physical emission coefficients from coal, oil and gas for each sector are provided by Eurostat Statistics (Eurostat, 1991) and are adapted using Spanish energy price data for producers and consumers. Another adjustment has been carried out on these coefficients to account for the amount of fossil fuel that is not used for combustion, as is the case in some industries and especially in the chemical sector (see Appendices). It is relevant to note that there is no domestic extraction of coal, oil or gas in the Basque country.

\subsection{Implementation of environmental policy}

As mentioned above, environmental policy in the Basque Country is modeled using a system of marketable pollution permits. Emission permits are exchanged between Basque economic agents, but the trade structure proposed imitates a situation in which similar climate policy objectives are also implemented within Spain; thus, the Basque Country is not able to transfer it's environmental problems to the rest of Spain.

The government fixes the number of permits to reflect the emission target and auctions them in the market. As there is perfect information, they are assigned efficiently at the equilibrium price. Theoretically this approach has the main advantages that it is cost effective, i.e. targets are reached at the minimum cost, and that is effective, i.e. government can be sure targets are achieved by controlling the number of permits. Furthermore, the tradable pollution permits approach is a natural way of modelling optimal abatement policies in an AGE structure; permits can be treated as another commodity with its own equilibrium price where demand equals supply and the market clears (cf. Dellink, 2005).

In the benchmark, permits are distributed for free according to benchmark emissions by agent; there is no scarcity and the price of permits in the market is zero. In the counterfactual policy scenarios the government auctions a limited number of permits. The substitution possibilities between inputs govern the way the model adapts to policy implementation and the competition between the polluters for the scarce permits ensures that reduction is achieved at minimum cost. These adaptation effects can be summarized by the variations in the: i) mix of energy use: from $\mathrm{CO}_{2}$ intensive 
fuels to cleaner ones; ii) production structure: substitution between inputs used for production; iii) economic structure: increasing the production of cleaner sectors and decreasing the dirtier ones and, finally, iv) scale of economy: reducing economic activity.

Other abatement options such as end of pipe or process oriented technologies are not considered because we suppose that they are more costly than input substitution and fuel switch. This assumption is appropriate for short term policy analysis, simplifies calculations considerably and is common in most of the major energy-economic models (Bohringer \& Rutherford, 2002; Nordhaus, 1993). Finally, it should be noted that we are assessing exclusively the cost of abatement and not the benefits from lower emissions in the form of lower environmental damage or higher amenity values. This analysis is therefore limited to a cost-effectiveness analysis for the short term and we cannot claim whether the targets analyzed are efficient.

\section{Results}

The analysis focuses on the economic impacts of $\mathrm{CO}_{2}$ abatements in steps of $5 \%$ up to a limit of $30 \%$. Spain, including the Basque Country, is allowed to increase their greenhouse gases emission up to $15 \%$ according to the Kyoto protocol, but by 1999 emissions had increased by 29\%). This put the Kyoto reference target around a reduction of $15 \%$ in emissions from the base year. As it is not clear what the contribution of the Basque country in this national reduction effort will be, we explore a range of required emission reductions from 5 to $30 \%$.

The analysis starts with a discussion of the general effects and then turns the attention to some specific issues such as changes in energy consumption and sectoral production levels. The marginal abatement cost curve of progressive emission reductions is another interest result that this analysis can offer. AGE models use some parameters that are uncertain and, hence, the study is complemented with a systematic analysis of the sensitivity of the model with respect to the elasticities of substitution parameters to gain insight in the possible variations in results.

\subsection{General results}

The effects on macro-economic variables indicators are shown for each level of emission reduction in figure 5. As a general overview, we observe a decrease of all three variables for all levels of emission reductions. This result supports the idea that there are no free options to cut down emissions. It is also important to notice that higher levels of required emission reduction lead to larger decreases in variables and, hence, economic costs increase more than proportionately with increasing environmental policy levels; this is due to the non-linear functions in the model.

In Table 1 we present a general overview of the results for three levels of reduction; $10 \%, 20 \%$, and $30 \%$. Two indicators are presented to reflect the macro-economic impact of the policies: utility and GDP. Utility is a good indicator of the welfare costs of the policy; welfare changes can be calculated as a Hicksian Equivalent Varia- 
tion (EV) measure of the policy, as the AGE distinguishes changes in quantities and prices. It should however be stressed that the benefits of the policy, in terms of increased environmental quality, are not taken into account, and hence the utility losses only represent the cost-side of changes in total welfare. Utility decreases with $0.2 \%$ when emission levels are reduced by $10 \%$, but welfare losses increase to $0.7 \%$ and $1.2 \%$, respectively, as the policy becomes more stringent. GDP shows a reduction of $0.6 \%, 1.4 \%$ and $2.3 \%$, respectively. As consumption levels decrease less than investment, it is not surprising that GDP losses are larger than utility losses. The model is static so we do not account for the impact that a smaller level of investments has on future economic growth.

\section{FIGURE 5}

\section{GDP, Investment and Total Consumption reduction for different $\mathrm{CO}_{2}$ abatement levels}

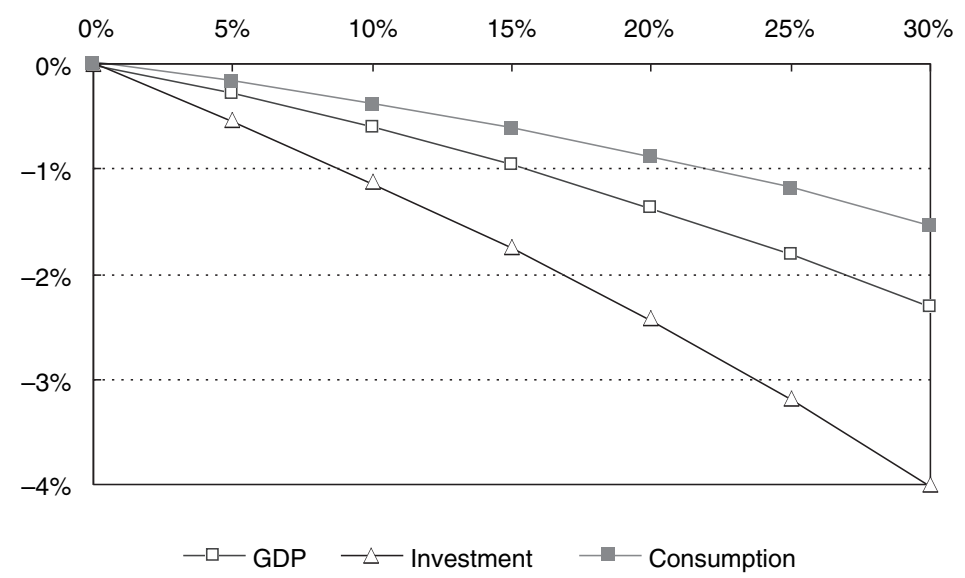

From the results it can be inferred that production is more affected than consumption, because the demand for produced goods by other production sectors is reduced, but especially because the use of goods for investments decreases substantially. Imports and exports generally go in the same direction, but there may be differences at a sectoral level. The increase in imports is somewhat smaller than the increase in exports, indicating that the trade surplus increases.

The environmental policy has a substantial impact on all economic sectors. As many sectors use fossil fuels for their activity, changes in economic structure are considerable. This can be seen by the big impacts on agricultural and industrial production and the smaller impact on the services sectors. In consumption the impact levels are much smaller and more evenly spread across sectors. This result also shows that consumers can limit their need to adapt their consumption patterns, while the production structure is adapted substantially to comply with the more stringent environmental policy. 
TABLE 1

General Results for abatement levels compared to benchmark 1995

\begin{tabular}{|c|c|c|c|}
\hline & $10 \%$ & $20 \%$ & $30 \%$ \\
\hline \multicolumn{4}{|l|}{ Macroeconomics results (\% volume variation) } \\
\hline Utility & $-0,21$ & $-0,51$ & $-0,94$ \\
\hline GDP & $-0,61$ & $-1,36$ & $-2,31$ \\
\hline Private Consumption & $-0,38$ & $-0,88$ & $-1,55$ \\
\hline Savings/ Investments & $-1,11$ & $-2,42$ & $-4,00$ \\
\hline Production & $-1,07$ & $-2,30$ & $-3,74$ \\
\hline \multicolumn{4}{|l|}{ International Trade results (\% volume variation) } \\
\hline Imports & $-1,36$ & $-2,91$ & $-4,70$ \\
\hline Exports & $-1,45$ & $-3,11$ & $-5,03$ \\
\hline Trade Balance & $-4,60$ & $-10,52$ & $-17,80$ \\
\hline \multicolumn{4}{|l|}{ Economic Structure 1 (\% volume variation) } \\
\hline Sectoral Production Agriculture & $-0,76$ & $-1,72$ & $-2,95$ \\
\hline Sectoral Production Industry & $-1,46$ & $-3,13$ & $-5,08$ \\
\hline Sectoral Production Services & $-0,57$ & $-1,25$ & $-2,05$ \\
\hline Private Consumption Agriculture & $-0,49$ & $-1,15$ & $-2,04$ \\
\hline Private Consumption Industry & $-0,72$ & $-1,65$ & $-2,87$ \\
\hline Private Consumption Services & $-0,22$ & $-0,51$ & $-0,91$ \\
\hline \multicolumn{4}{|l|}{ Energy $^{2}$ (\% volume variation) } \\
\hline Total Energy Use & $-5,50$ & $-11,45$ & $-17,96$ \\
\hline Energy consumption Producers & $-7,72$ & $-15,74$ & $-24,11$ \\
\hline Energy consumption Consumers & $-2,42$ & $-5,49$ & $-9,41$ \\
\hline \multicolumn{4}{|l|}{ Prices (index price $1995=1$ ) } \\
\hline Price of Capital & 1,00 & 1,00 & 1,00 \\
\hline Price of Labor & 0,99 & 0,98 & 0,97 \\
\hline Permit Price (euro / ton. $\mathrm{CO}_{2}$ eq.) & 13,60 & 32,61 & 60,16 \\
\hline \multicolumn{4}{|l|}{ Climate Policy and Closure rules } \\
\hline Total $\mathrm{CO}_{2}$ Emissions (\% volumen variation) & $-10,00$ & $-20,00$ & $-30,00$ \\
\hline \multicolumn{4}{|l|}{ Exchange rate index (\% variation from index price } \\
\hline $1995=1)$ & 1,00 & 1,00 & 1,00 \\
\hline Goverment Consumption (\% volumen variation) & 0,00 & 0,00 & 0,00 \\
\hline
\end{tabular}

${ }^{1}$ All sectors are grouped in three categories: Agriculture (1), Industry (2 a 16) and Services (17 a 22 ).

${ }^{2}$ Energy groups the consumption of coal, oil, gas and electricity.

It is obvious that the largest source of emission reduction comes from the reduction in the use of fossil fuels. Total use of energy decreases by $5 \%$ for a reduction of $10 \%$ in $\mathrm{CO}_{2}$ emissions and by $18 \%$ for a reduction of $30 \%$. This approximately reflects that changes in the fuel mix and energy savings both are critical in achieving the required emission reductions. Consumer's reduction of energy use is much higher than the reduction of energy use by producers, reflecting the fewer possibilities for consumers to switch between different energy carriers as compared to producers. 


\subsection{Sectoral results}

Multi-sectoral AGE's are an appropriate tool to identify how policy changes affect different sectors. Any shock in the initial general equilibrium situation will result in a different allocation of the resources and, consequently, sectors will be affected in different ways. These effects are much more diverse than the macroeconomic results; dirty sectors are affected more than clean ones and some sectors may even benefit from environmental policy. Figure 6 shows the results for sectoral domestic production for a reduction in emissions of 10\%, 20\% and 30\% level.

Domestic production decreases for almost all sectors and for all levels of $\mathrm{CO}_{2}$ abatement. The group of sectors that is severely affected is, not surprisingly, the group of highly polluting and energy-intensive industries. This includes not only the energy sectors themselves, but also for instance the transport sectors. The impact is especially severe for the oil refinery industry. These impacts are a combination of changes on the supply side, where high emission intensities make the production process more costly, and the demand side, where higher prices for goods induce demand reductions. Transport by water is more affected than other transport sectors because of the indirect effects; though in absolute terms this is a very small sector, and the influence on the rest of the economy is very limited (see table A.2). Agricultural production is reduced moderately, but this effect would be much bigger if other GHGs had been taken into account, as it is very intensive in methane $\left(\mathrm{CH}_{4}\right)$ and nitrous oxide $\left(\mathrm{N}_{2} \mathrm{O}\right)$ emissions.

The service sectors are relatively well-off as the proportions of non polluting production factors, labor and capital, are much higher than in other sectors. Moreover, the services sectors represent around $40 \%$ of total economic production (see Appendices). In general, these results indicate a restructuring of the economy from energy and dirty industrial sectors toward the services sectors.

The decline in the total use of energy is substantial, but there are important differences between coal, oil, gas and electricity. Figure 7 illustrates that use of coal is reduced much more than the use of the other energy carriers and a 30\% required reduction in emissions induces a reduction in coal use of $42 \%$. Oil use is reduced less than coal, but more than gas and electricity. These changes in fuel mix clearly reflect the underlying differences in $\mathrm{CO}_{2}$ emission intensities of the different energy carriers (cf. Appendices). Note that the reduction in electricity use is the result of an indirect effect: the sector itself is not coupled to emissions, but only through the use of fossil fuels in the production of electricity.

Results for consumption patterns can be found in figure 8 . The consumption of products from Oil refineries shows a large reduction that comprises changes in heating from oil to other alternatives. Consumption of goods that are $\mathrm{CO}_{2}$-intensive in production also reduces relatively much, induced by the price increases of these goods and services. Reductions in the consumption of services remain limited, and the non-commercial services sector even increases very slightly. These results indicate that consumption patterns change to some extent towards cleaner products. 
FIGURE 6

Sectoral Production volumes changes (\%) for different abatement levels

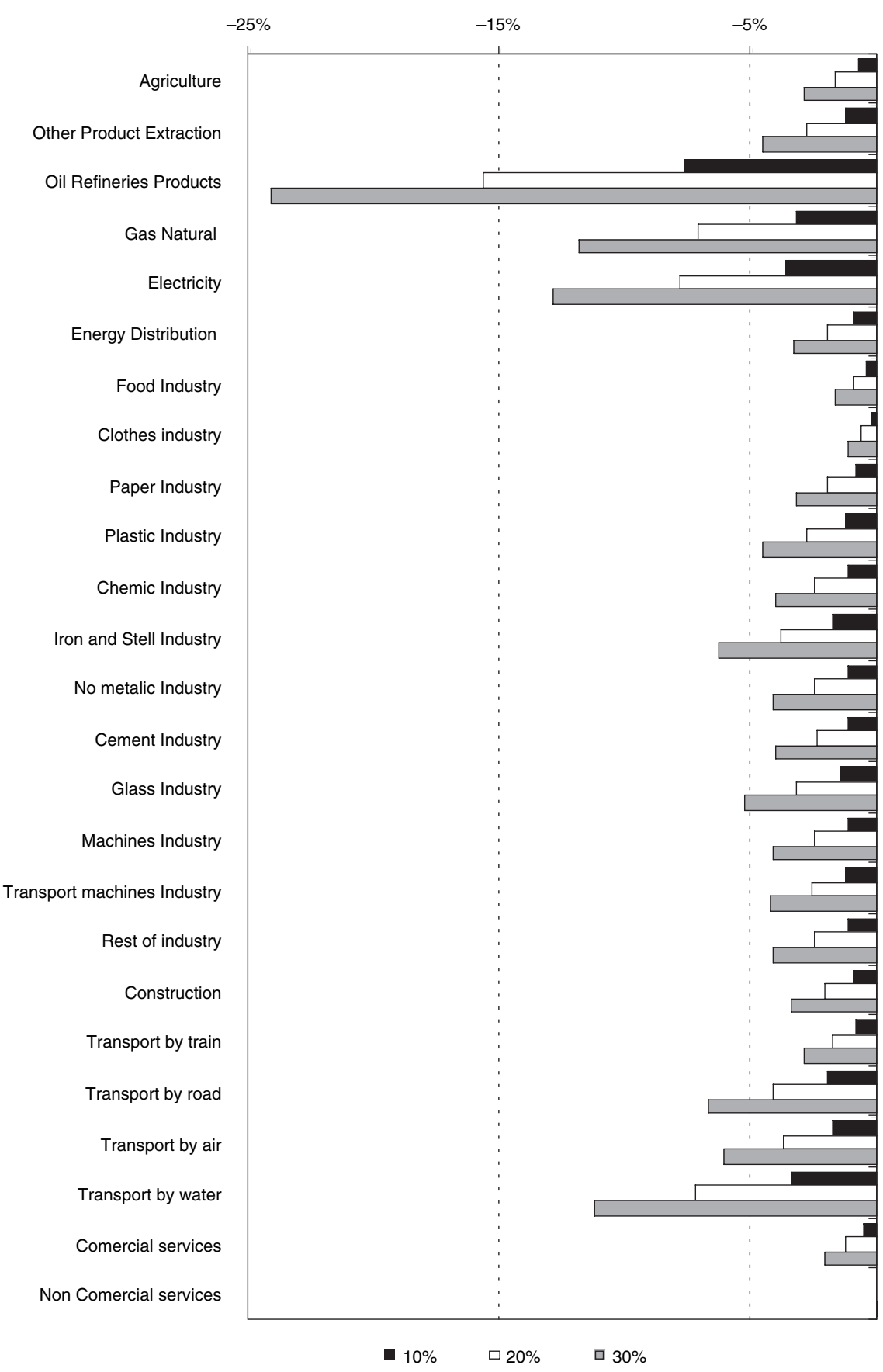




\section{FIGURE 7}

Total changes in energy use for different abatement levels

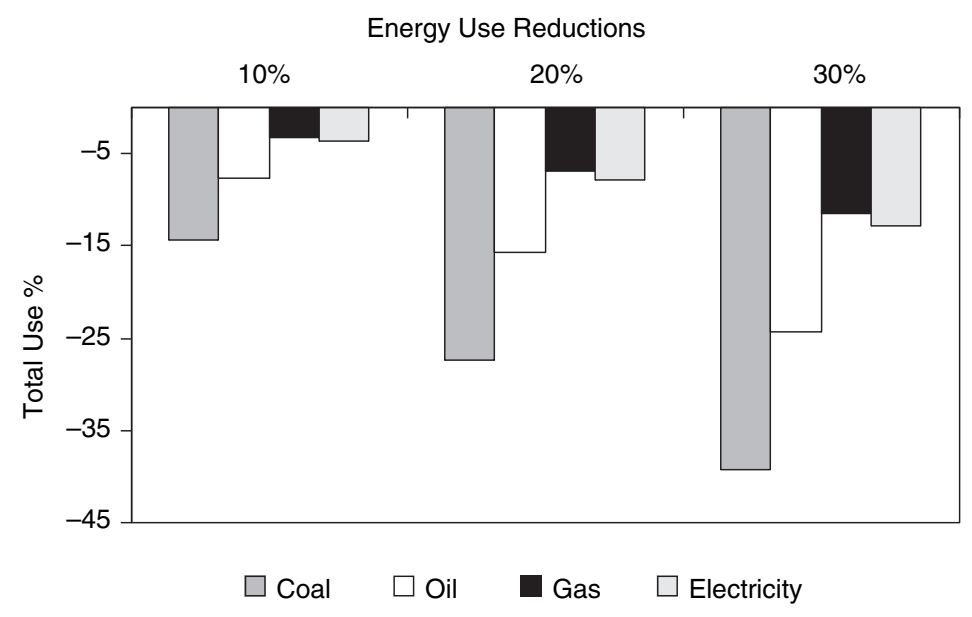

\subsection{Marginal abatement cost}

AGE models can give us the implicit marginal abatement costs (MAC) at different levels of emission reduction (Ellerman and Deceaux, 1998). As solutions found for each policy level are cost-effective, emission permit prices reflect marginal abatement costs from a macroeconomic perspective. The advantage of this way of calculating abatement cost curves is that both the direct and indirect costs are incorporated in the estimate, whereas bottom-up studies of marginal abatement costs tend to ignore indirect effects (cf. Dellink, 2005). Nonetheless, the quality of the MAC curves depends on the alternative options for emission reduction that have been introduced in the model. In line with other climate-economy models, we ignore end-of-pipe options as they are prohibitively costly for the range of emission reductions we investigate. This implies that the MAC we obtain cannot easily be extrapolated to more farreaching emission reduction targets. The marginal abatement cost curve obtained is presented in figure 9 in euro per ton of $\mathrm{CO}_{2}$.

The marginal cost for the reduction range considered is between 0 and 60 Euro per Ton of $\mathrm{CO}_{2}$, in line with other studies (Weyant, 2004). The price of emissions increases more than proportionally for stricter environmental policy; marginal abatement costs increase more and more rapidly as cheaper options are gradually exhausted. For a reduction of $15 \%$ in emission, similar to the Kyoto reference target, the cost per ton of $\mathrm{CO}_{2}$ would be 21 euro per ton of $\mathrm{CO}_{2}$. These results are good reference points for policy makers that like to know ex-ante what approximately the price of emission permits could be in a permit market system for a (unilateral) environmental policy within the Basque Country, or that want to implement a carbon tax. 
FIGURE 8

Sectoral Consumption volumes changes (\%) for different abatement levels

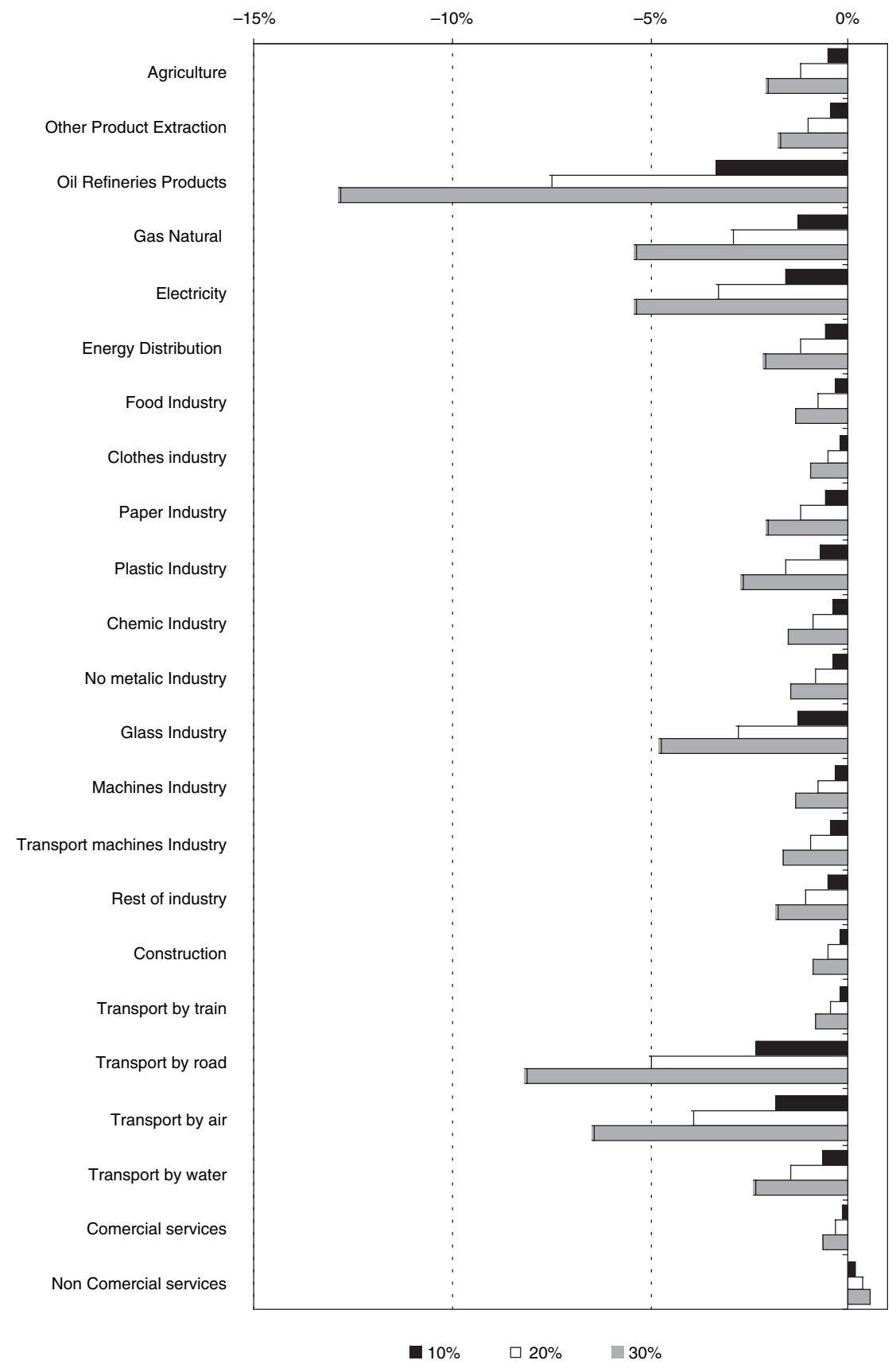




\section{FIGURE 9}

Marginal abatement cost for different abatement levels

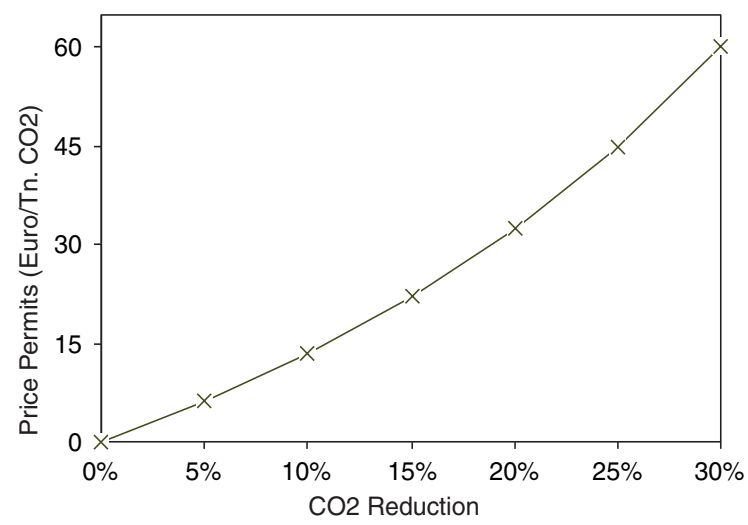

\subsection{Unilateral versus multilateral policy}

The environmental policy investigated above is implemented unilaterally in a regional economy, though the trade setting with respect to the Rest of Spain mimics a similar Spanish policy. However, climate change policy depends highly on global agreements and on international (European) emission trading market systems. In this section we explore the impacts of climate policy on a regional economy in a context in which the environmental policy is implemented multilaterally for all countries the Basque region trades with.

The Armington specification on trade allows some substitutability between domestic and foreign goods, and we assumed that world market prices are constant. As the model does not specify explicitly other countries, it is necessary to make an approximation that resembles this situation by assuming that relative world market prices change in the same way as relative domestic prices do (Dellink, 2005). This is true if sectoral impacts of environmental policy are similar across countries and means that import and export shares in trade goods will not change. This specification can be implemented by assuming that Armginton $\left(\sigma^{A}\right)$ and Transformation $\left(\sigma^{T}\right)$ elasticities on trade are zero; in this case, there is no possibility of substitution between domestic and foreign goods and both are demanded in fixed proportion.

The results obtained with the multilateral specification differ from those observed in the unilateral specification. As there is no possibility to specialize on clean goods, especially consumption patterns are affected more severely. The welfare costs are around two third higher in the multilateral scenario as illustrated in figure 10 . This results is often found in AGE models (cf. Gerlagh et al., 2002), contradicts the common argument that environmental policy negatively affects international competitiveness and shows that environmental friendly specialization can turn environmental policy into a opportunity or advantage. 
FIGURE 10

Welfare change (\%) for different abatement levels in a unilateral and multilateral scenario

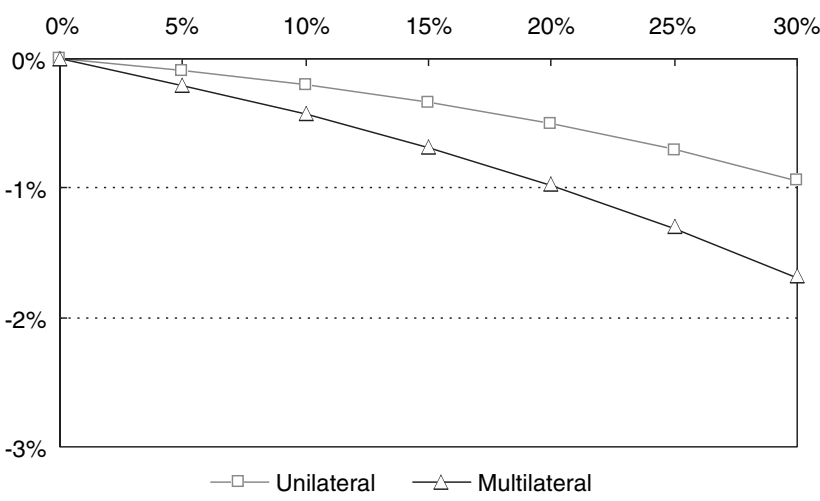

\section{Sensivity Analysis}

Sensitivity analysis is essential for testing the robustness of any calibrated model. Calibration with systematic sensitivity analysis is the most common practice with AGE models as it gives a good measurement of the cost and deviations from variations in parameter values. We have performed sensitivity analyses on all the elasticities used in the production, trade and utility functions, for the case where the emissions are reduced by $15 \%$ compared to the benchmark. Two simulations are considered; in the low simulation, the value of one of the elasticities is the half of the base case value and in high simulation the value is doubled.

The results in figure 11 illustrate the range of variation in GDP for the different simulations. GDP turns out to be sensitive to the top level in the nested CES structure, as is the case of Energy \& Value added and Consumption \& Leisure. Moreover, the trade elasticities have a substantial impact, in line with the analysis of the multilateral specification above. The elasticity between Labor and Capital is also significant as value added represent a very high proportion of all the inputs used in production. The rest of elasticities do not influence considerably final results.

\section{Conclusions}

In this article, the economic impact of $\mathrm{CO}_{2}$ abatement policies for the Basque Country is analyzed. We use a static multi-sectoral applied general equilibrium (AGE) model with specific attention to energy use and $\mathrm{CO}_{2}$ emissions. The instrument used to implement environmental policy is a tradable emission permit system. The model quantifies the effects on macro-economic variables, energy consumption, 
FIGURE 11

Elasticities Sensitivity analysis results for an abatement level of $15 \%$

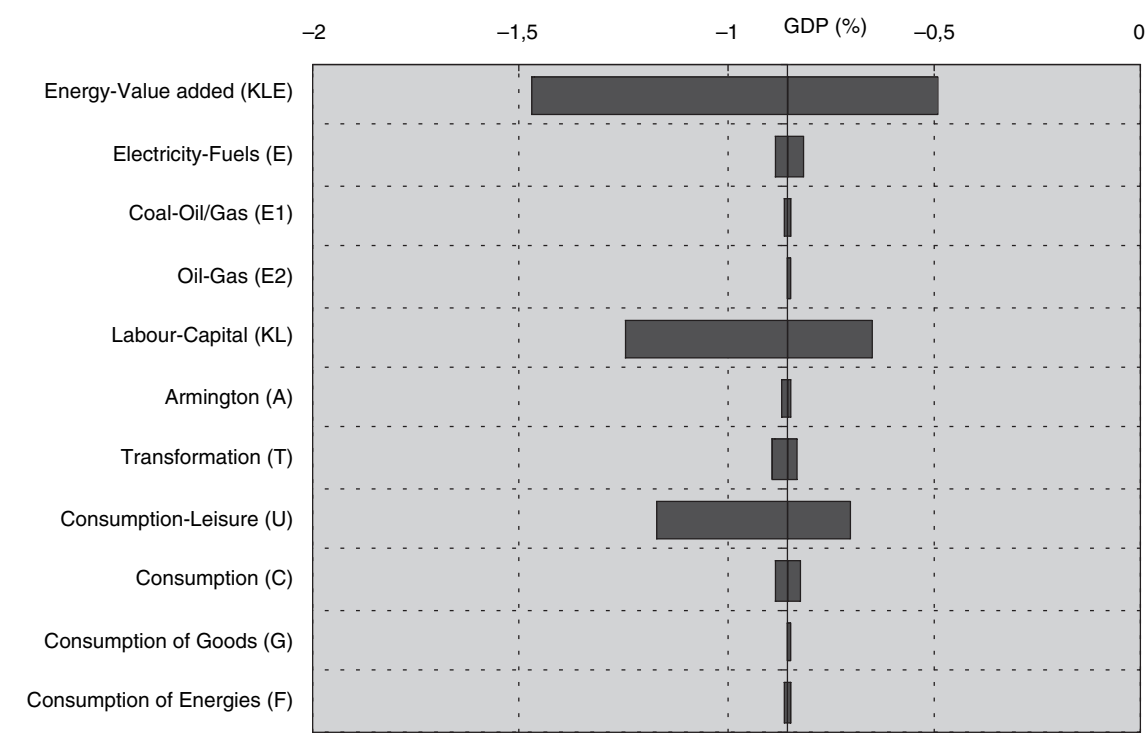

and sectoral production activity, and provides insights into the least cost effects for different emission reduction goals.

Some caveats should be considered for putting these results in perspective. Concerning the model, it should be mentioned that the absence of end-of-pipe abatement options restricts the appropriate scope of the analysis to environmental policy targets that are not too farreaching. Moreover, it is important to remind that the lack of accounting of the benefits of environmental policy limits a proper welfare analysis. There are also caveats concerning the data used; this is the case for the elasticities of substitution, for which an econometric estimation would be valuable. Finally, the details of the interactions between the Basque Country and the Rest of Spain can be improved. This includes among others financial transfers, permit trading between both regions and perhaps even a full disaggregration of the Basque economy in the GTAP or GTAP-E database. Any progress on these issues will lead to a more realistic model and better simulations results.

There are several conclusions that can be obtained from this empirical analysis. A policy to cut $\mathrm{CO}_{2}$ emissions in the Basque Country will have to face some costs. However, there are many possibilities of fuel substitution to make this reduction not so costly: a reduction in emissions of $15 \%$ induces a decrease in GDP of approximately $1 \%$. The required emission reductions are achieved through a combination of fuel switch, away from coal and oil, and a restructuring from the «dirty» energy and industrial sectors toward the «cleaner» services sectors. Trade is an important factor for keeping the costs low; the welfare costs are substantially higher if the circumstances 
on the international markets do not allow a specialization of the domestic economy in clean production. Finally, it is estimated that the price of $\mathrm{CO}_{2}$ emission permits reaches just over 60 Euro per ton for the more stringent policy target of $30 \%$ emission reduction.

The purpose of this analysis was to contribute to a better understanding of the economic impacts of climate change policies applied to Basque Country. As we have seen, the economic cost of pollution reduction is limited by the substitution possibilities and fuel switch options, but some sacrifice has to be made. We hope these results will assist in a better informed climate policy action in the Basque Country, considering the trade-offs between economic costs and environmental quality.

\section{References}

Armington, P.S. (1969). «A theory of production distinguished by place of production». IMF Staff Papers, 16:159-178.

Bohringer, C. y Rutherford, T. (2002). «Carbon abatement and international spillovers: a decomposition of general equilibrium effects». Environmental and Resource Economics, vol. $22(3): 391-417$.

Dellink, R.B. (2005). Modelling the costs of environmental policy: a dynamic applied general equilibrium assessment. Edward Elgar Publishing, Cheltenham.

Ellerman, A. y Deceaux, A. (1998). Analysis of Post-Kyoto $\mathrm{CO}_{2}$ emissions trading using marginal abatement curves. Joint Program on the Science and Policy of Global Change, MIT and Cambridge.

EUROSTAT. Energy and environment statistics. European Statistics, Luxemburg. http://www.eurostat.eu.int/.

EUSTAT (2000). Input-Output Tables. Instituto Vasco de Estadística, Vitoria. http://www.eustat.es/.

EVE (2000). Energy data of the Basque Country 1999. Ente Vasco de la Energía, Bilbao. http://www.eve.es/.

Gerlagh, R., Dellink, R.B., Hofkes M.W. y Verbruggen, H. (2002). «A measure of Sustainable National Income for The Netherlands». Ecological Economics, 41:157-174.

Ginsburgh, V. y Keyzer, M.A. (1997). The structure of applied General Equilibrium Models. MIT Press, Cambridge.

Gómez A., Faehn, T. y Kverndokk, S. (2004). Can carbon taxation reduce Spanish unemployment? Working Paper, Univ. of Oslo.

Hayashi, F. (1982). «Tobin's q, rational expectations and optimal investment rule». Econometrica, 50:213-224.

Hertel, T. (1997). Global trade analysis: modeling and applications. Cambridge University Press, Cambridge.

IEA (1998). Energy Statistics of OECD Countries 1995-1996. International Energy Agency, Paris.

Kemfert, C. y Welsch, H. (2000). «Energy-Capital-Labor substitution and the economics effects of $\mathrm{CO}_{2}$ abatement: evidence for Germany». Journal of Policy Modelling, 22:641660.

De Miguel, C., Labandeira, X. y Manzano, B. (2006). «The Effects of a Sudden $\mathrm{CO}_{2}$ Reduction in Spain», en (eds.) Economic Modelling of Climate Change and Energy Policies. Edward Elgar, Cheltenham (Inglaterra). 
Manresa, A. y Sancho, F. (2004). «Energy intensities and $\mathrm{CO}_{2}$ emissions in Catalonia: a SAM analysis. International Journal of Environment». Workplace and Employment, 1:96-106.

Nordhaus, W. (1993). «Rolling the "DICE": An Optimal Transition Path for Controlling Greenhouse Gases». Resource and Energy Economics, 15 (1):27-50.

Rutherford, T. (1999). «Applied General Equilibrium Modelling with MPSGE as a GAMS subsystem: an overview of the modeling framework and syntax». Computational Economics, 14:1-46.

Rutherford, T. y Paltsev, S. (2000). GTAP-Energy in GAMS: The Dataset and Static Model. Univ. of Colorado. https://www.gtap.agecon.purdue.edu/.

Shoven, J. y Whalley, J. (1992). Applying General Equilibrium. Cambridge University Press, Cambridge.

Springer, U. (2003). «The market for tradable GHG permits under the Kyoto Protocol: a survey of model studies». Energy Economics, 25 (5), 27-551.

Weyant, J.P. (2004). «Introduction and overview to the Special Issue: Alternative technology strategies for climate change policy». Energy Economics, 26:501-515. 


\section{Appendices}

\section{A1. Model Equations}

\section{Production}

Production function for goods ${ }^{4} \forall j \in(1, \ldots, J)$

$$
Y_{j}=C E S\left(Y_{l, j}^{I D}, \ldots, Y_{l, j}^{I D} ; K_{j} ; L_{j} ; E_{j}^{P} ; \sigma^{Y}, \sigma^{K L E}, \ldots, \sigma^{E 2}\right)^{5}
$$

Zero profit condition $\forall j \in(1, \ldots, J)$

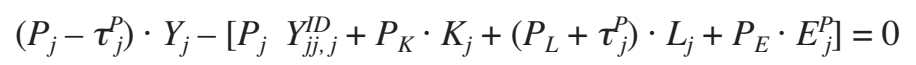

\section{Trade}

Total supply from import and production for goods ${ }^{6} \forall j \in(1, \ldots, J), \forall r \in(1, \ldots, R)$

$$
Y_{j}^{T S}=C E S\left(Y_{j}, M_{j, r} ; \sigma^{A}\right)
$$

Domestic demand and export from total demand $\forall j \in(1, \ldots, J), \forall r \in(1, \ldots, R)$

$$
Y_{j}^{T D}=C E S\left(Y_{j}^{D}, X_{j, r} ; \sigma^{T}\right)
$$

Closure rule on trade $\forall j \in(1, \ldots, J), \forall r \in(1, \ldots, R)$

$$
\sum_{j=1}^{J} \sum_{r=1}^{R} P x\left(M_{j, r}-X_{j, F}\right)=X D \text { with } P_{x} \text { fixed. }
$$

Market balance $\forall j \in(1, \ldots, J)$

Goods markets balance

$$
Y_{j}^{D D}=\sum_{j j=1}^{J} Y_{j j, j}^{I D}+C_{j}+G_{j}+I_{j}
$$

Capital markets balance $\forall j \in(1, \ldots, J)$

$$
\sum_{j=1}^{J} K_{j}=\bar{K}
$$

Labor markets balance $\forall j \in(1, \ldots, J)$

$$
\sum_{j=1}^{J} L_{j}=\bar{L}
$$

${ }^{4}$ The nesting structure for production function is represented graphically in figure 2 .

${ }^{5}$ CES functions have the following structure for the case of two level of nesting and two inputs:

In the first level $Y=\operatorname{CES}\left(X_{1}, X_{2} ; \sigma\right)=\left(a_{1} X_{1}^{\sigma-1 / \sigma}+a_{2} X_{2}^{\sigma-1 / \sigma}\right)^{\sigma-1 / \sigma}$ and in the second level $X_{2}=C E S\left(X_{3}\right.$, $\left.X_{2} ; \psi\right)=\left(a_{3} X_{3}^{\psi-1 / \psi}+a_{4} X_{4}^{\psi-1 / \psi}\right)^{\psi / \psi-1}$, where $a_{1}, a_{2}, a_{3}, a_{4}$ are parameters and $\sigma, \psi$ represent the elasticities of substitution between the inputs.

${ }^{6}$ The nesting structure for trade function is represented graphically in figure 3. 
Savings/investments balance $\forall j \in(1, \ldots, J)$

$$
S=\sum_{j=1}^{J} P_{j} \cdot I_{j}+X D
$$

\section{Consumer}

Utility function representative consumer ${ }^{7} \forall j \in(1, \ldots, J)$

$$
U_{H}=C E S\left(C_{1}, \ldots, C_{J} ; L S ; E^{C}: \sigma^{U}, \ldots, \sigma^{F}\right.
$$

Income balance representative consumer

$\forall j \in(1, \ldots, J)\left[P_{K} \cdot K+P_{L} \cdot L+T\right]-\left[\sum_{j=1}^{J}\left(P_{J}+\tau_{j}^{C}\right) \cdot C_{J}+P_{E} \cdot E^{C}+S\right]=0$

\section{Government}

Utility function government $\forall j \in(1, \ldots, J)$

$$
U^{G}=C E S\left(G_{1}, \ldots, G_{J}\right)=\bar{U}_{G}
$$

Income balance government $\forall j \in(1, \ldots, J)$

$$
\begin{gathered}
{\left[P_{E} \cdot\left(E^{P}+E^{C}\right)+\sum_{j=1}^{J}\left(P_{L} \cdot \tau^{L} \cdot L_{j}+P_{J} \cdot \tau_{j}^{C} \cdot C_{j}+P_{j} \cdot \tau_{j}^{P} \cdot Y_{j}\right)\right]-} \\
-\left[\sum_{j=1}^{J} P_{J} \cdot G_{j}+T\right]=0
\end{gathered}
$$

\section{Environment}

$\mathrm{CO}_{2}$ Emission on production $\forall j \in(1, \ldots, J) e \in($ coal, oil, gas $)$

$$
E_{J}^{P}=\sum_{e=1}^{3} \alpha_{e} \cdot Y_{e, j}^{I D}
$$

$\mathrm{CO}_{2}$ Emission on consumption $\forall j \in(1, \ldots, J) e \in$ (coal, oil, gas)

$$
E^{C}=\sum_{e=1}^{3} \beta_{e} \cdot C
$$

$\mathrm{CO}_{2}$ Emission permits market balance

$$
E=\sum_{j=1}^{J} E_{j}^{P}+E^{C}=\overline{\text { target }}
$$

\footnotetext{
7 The nesting structure for utility function is represented graphically in figure 4 .
} 


\section{A2. Symbols}

\section{Indices}

\begin{tabular}{cll}
\hline Label & \multicolumn{1}{c}{ Entries } & \multicolumn{1}{c}{ Description } \\
\hline$j, j j$ & $1, \ldots, \mathrm{J}$ & Sectors, Intermediate Inputs or Goods \\
$n$ & $1, \ldots, \mathrm{N}$ & Non-Energy Sectors, Intermediate Inputs or Goods \\
$e$ & Coal, Oil, Gas & Fossil Fuels \\
$r$ & ROS, ROW & Regions; Rest of Spain and Rest of the World \\
\hline
\end{tabular}

\section{Parameters}

\begin{tabular}{ll}
\hline Label & \multicolumn{1}{c}{ Description } \\
\hline$\sigma^{Y}$ & Substitution elasticity between energy-capital-labor and intermediate inputs \\
$\sigma^{K E L}$ & Substitution elasticity between energy and capital-labor for sector $\mathrm{j}$ \\
$\sigma_{j}^{K L}$ & Substitution elasticity between labor and capital for sector $\mathrm{j}$ \\
$\sigma^{E}$ & Substitution elasticity between electricity and fossil fuels in production \\
$\sigma^{E 1}$ & Substitution elasticity between coal and liquid fossil fuels in production \\
$\sigma^{E 2}$ & Substitution elasticity between oil and gas in production \\
$\sigma^{U}$ & Substitution elasticity between consumption and leisure \\
$\sigma^{C}$ & Substitution elasticity between energy and non-energy goods \\
$\sigma^{F}$ & Substitution elasticity between energy goods in consumption \\
$\sigma^{G}$ & Substitution elasticity between non-energy goods in consumption \\
$\sigma^{A}$ & Armington elasticity between domestic production and imports \\
$\sigma^{T}$ & Transformation elasticity between domestic demand and exports \\
$\tau_{j}^{L}$ & Labor tax rate in sector $\mathrm{j}$ \\
$\tau_{j}^{P}$ & Production net tax rate in sector $\mathrm{j}$ \\
$\tau_{j}^{C}$ & Consumption tax rate in good $\mathrm{j}$ \\
$T$ & Lump sum transfers between government and consumer \\
$\alpha_{e}$ & Production $\mathrm{CO}_{2}$ emission coefficient of coal, oil and gas \\
$\beta_{e}$ & Consumption $\mathrm{CO}_{2}$ emission coefficient of coal, oil and gas \\
\hline
\end{tabular}




\section{Variables}

\begin{tabular}{|c|c|}
\hline Label & Description \\
\hline$Y_{j}$ & Production in sector $j$ \\
\hline$Y_{j, j j}^{I D}$ & Intermediate demand of input $j j$ in sector $j$ \\
\hline$Y_{J}^{D}$ & Domestic demand of good $j$ \\
\hline$Y_{j}^{T S}$ & Total supply of good $j$ \\
\hline$Y_{j}^{T D}$ & Total demand of good $j$ \\
\hline$M_{j, r}$ & Imports of good $j$ from region $r$ \\
\hline$X_{j, r}$ & Exports of good $j$ from region $r$ \\
\hline$K_{j}$ & Capital demand by sector $j$ \\
\hline$L_{j}$ & Labour demand by sector $j$ \\
\hline$X D$ & Trade deficit with rest of the regions \\
\hline$U_{H}$ & Utility for Consumers \\
\hline$\overline{U_{G}}$ & Utility for Consumers \\
\hline$L S$ & Leisure \\
\hline$C_{j}$ & Private Consumption of good $j$ \\
\hline$S$ & Savings \\
\hline$G_{j}$ & Public Consumption of good $j$ \\
\hline$K$ & Capital supply \\
\hline$L$ & Labour supply \\
\hline$I_{j}$ & Investment in sector $j$ \\
\hline$E_{J}^{P}$ & $\mathrm{CO}_{2}$ emissions by producer $j$ \\
\hline$E^{C}$ & $\mathrm{CO}_{2}$ emissions by consumers \\
\hline E & Total $\mathrm{CO}_{2}$ emissions \\
\hline$\overline{\text { target }}$ & $\mathrm{CO}_{2}$ emission targets \\
\hline$P_{j}$ & Equilibrium market price of good $j$ \\
\hline$P_{k}$ & Equilibrium market price of capital \\
\hline$P_{L}$ & Equilibrium market price of labour \\
\hline$P_{E}$ & Equilibrium market price of emission permits \\
\hline$P_{X}$ & Equilibrium real exchange rate (price of foreign good) \\
\hline$P_{I}$ & Equilibrium price of investment \\
\hline
\end{tabular}




\section{A3. Social Accounting matrix and data}

TABLE A1

SAM 1999 for Basque Country (mln. euros)

\begin{tabular}{|c|c|c|c|c|c|c|c|c|c|c|c|c|c|c|c|c|c|c|}
\hline & Y1 & Y2 & Y3 & Y4 & Y5 & Y6 & $\mathrm{Y7}$ & Y8 & Y9 & $\mathrm{Y} 10$ & Y11 & Y12 & Y13 & Y14 & Y15 & Y16 & Y17 & Y18 \\
\hline$\overline{\mathrm{Y} 1}$ & 676 & 0 & 0 & 0 & 0 & 0 & 0 & 0 & -536 & -35 & -224 & -22 & -11 & 0 & 0 & 0 & 0 & $\overline{0}$ \\
\hline Y2 & 0 & 0 & 0 & 0 & -7 & -1 & -39 & 0 & 0 & 0 & 0 & 0 & 0 & -1 & -2 & -4 & 0 & 0 \\
\hline Y3 & 0 & 0 & 0 & 0 & -929 & -118 & 0 & 0 & 0 & 0 & 0 & 0 & 0 & 0 & 0 & 0 & 0 & 0 \\
\hline Y4 & 0 & 0 & 0 & 152 & 0 & 0 & 0 & 0 & -7 & 0 & -5 & 0 & -17 & -16 & -158 & -2 & -3 & -6 \\
\hline Y5 & -31 & 0 & 0 & -3 & 1449 & 0 & -87 & -3 & -3 & -1 & -7 & -6 & -3 & -5 & -2 & -2 & 0 & -2 \\
\hline Y6 & 0 & 0 & 0 & 0 & 0 & 184 & -31 & 0 & -2 & -1 & -7 & -5 & -6 & -39 & -4 & -2 & -10 & -7 \\
\hline Y7 & -2 & 0 & 0 & -2 & -4 & -1 & 672 & -31 & -16 & -3 & -60 & -40 & -48 & -284 & -17 & -6 & -10 & -87 \\
\hline Y8 & -2 & 0 & 0 & -1 & -10 & -1 & 0 & 570 & -5 & -1 & -16 & -15 & -21 & -37 & -21 & 0 & -9 & -19 \\
\hline Y9 & -40 & 0 & 0 & -1 & 0 & 0 & 0 & 0 & 1846 & -10 & -5 & 0 & -10 & 0 & 0 & 0 & 0 & -1 \\
\hline Y10 & -3 & 0 & 0 & 0 & 0 & 0 & 0 & 0 & -1 & 186 & -1 & -8 & -1 & -3 & -2 & 0 & -1 & -2 \\
\hline Y11 & -1 & 0 & 0 & 0 & 0 & 0 & 0 & 0 & -54 & 0 & 1797 & -19 & -27 & -10 & -23 & 0 & -15 & -49 \\
\hline Y12 & -2 & 0 & 0 & 0 & 0 & 0 & 0 & 0 & -16 & -1 & -11 & 1847 & -15 & -1 & -13 & 0 & -1 & -131 \\
\hline Y13 & -22 & 0 & 0 & -6 & -16 & -2 & 0 & -53 & -8 & -7 & -86 & -627 & 1033 & -40 & -64 & 0 & -13 & -111 \\
\hline Y14 & 0 & 0 & 0 & -1 & 0 & 0 & 0 & 0 & -1 & 0 & -1 & -28 & -13 & 2396 & -743 & 0 & -2 & -939 \\
\hline Y15 & 0 & 0 & 0 & -1 & 0 & 0 & 0 & 0 & 0 & 0 & -2 & -3 & -1 & -81 & 3445 & 0 & -1 & -465 \\
\hline Y16 & 0 & 0 & 0 & 0 & 0 & 0 & 0 & 0 & 0 & 0 & -2 & 0 & 0 & -3 & -66 & 87 & 0 & -1 \\
\hline Y17 & 0 & 0 & 0 & 0 & 0 & 0 & 0 & 0 & -34 & 0 & -1 & -4 & -1 & 0 & -2 & 0 & 280 & -16 \\
\hline Y18 & -15 & 0 & 0 & -5 & -23 & -3 & -7 & -55 & -9 & -2 & -34 & -34 & -18 & -83 & -94 & -1 & -5 & 5309 \\
\hline Y19 & -10 & 0 & 0 & 0 & 0 & 0 & 0 & 0 & 0 & 0 & 0 & 0 & 0 & 0 & 0 & 0 & 0 & -28 \\
\hline Y20 & -6 & 0 & 0 & -3 & 0 & 0 & 0 & -2 & -15 & -1 & -8 & -5 & -14 & -31 & -66 & 0 & -4 & -141 \\
\hline Y21 & -1 & 0 & 0 & -8 & -4 & 0 & -3 & -25 & -7 & 0 & -9 & -5 & -5 & -13 & -21 & 0 & -1 & -27 \\
\hline Y22 & 0 & 0 & 0 & 0 & 0 & 0 & 0 & 0 & -2 & 0 & -4 & -6 & -8 & -22 & -11 & 0 & -1 & -8 \\
\hline Y 23 & -8 & 0 & 0 & -18 & -4 & 0 & 0 & -2 & -55 & -4 & -77 & -54 & -67 & -77 & -119 & -1 & -12 & -134 \\
\hline Y24 & -1 & 0 & 0 & 0 & 0 & 0 & 0 & 0 & -2 & -1 & -1 & 0 & 0 & 0 & 0 & 0 & 0 & -2 \\
\hline Y25 & -2 & 0 & 0 & -1 & -48 & -6 & 0 & 0 & 0 & 0 & -3 & -3 & -10 & -28 & -10 & 0 & -2 & -5 \\
\hline Y26 & -34 & 0 & 0 & -28 & -110 & -14 & -45 & -155 & -253 & -38 & -355 & -184 & -233 & -343 & -399 & -2 & -25 & -939 \\
\hline Y27 & -3 & 0 & 0 & 0 & -1 & 0 & -1 & -6 & -1 & 0 & -6 & 0 & -5 & -7 & -11 & 0 & 0 & -22 \\
\hline $\mathrm{L}$ & -71 & 0 & 0 & -21 & -32 & -4 & -64 & -40 & -218 & -44 & -392 & -352 & -182 & -540 & -785 & -15 & -67 & -1015 \\
\hline K & -420 & 0 & 0 & -46 & -107 & -14 & -305 & -192 & -283 & -27 & -384 & -315 & -268 & -572 & -594 & -47 & -80 & -890 \\
\hline TAXL & -22 & 0 & 0 & -6 & -8 & -1 & -40 & -10 & -64 & -12 & -97 & -112 & -47 & -159 & -217 & -4 & -18 & -288 \\
\hline SUBP & 39 & 0 & 0 & 0 & 0 & 0 & 0 & 7 & 5 & 2 & 8 & 4 & 2 & 5 & 9 & 0 & 1 & 34 \\
\hline TAXP & -19 & 0 & 0 & -1 & -146 & -19 & -50 & -3 & -259 & 0 & -7 & -4 & -4 & -6 & -10 & -1 & -1 & -8 \\
\hline TAXC & 0 & 0 & 0 & 0 & 0 & 0 & 0 & 0 & 0 & 0 & 0 & 0 & 0 & 0 & 0 & 0 & 0 & 0 \\
\hline TAXLS & 0 & 0 & 0 & 0 & 0 & 0 & 0 & 0 & 0 & 0 & 0 & 0 & 0 & 0 & 0 & 0 & 0 & 0 \\
\hline Savings & 0 & 0 & 0 & 0 & 0 & 0 & 0 & 0 & 0 & 0 & 0 & 0 & 0 & 0 & 0 & 0 & 0 & 0 \\
\hline Tradebal & 0 & 0 & 0 & 0 & 0 & 0 & 0 & 0 & 0 & 0 & 0 & 0 & 0 & 0 & 0 & 0 & 0 & 0 \\
\hline Total & 0 & 0 & 0 & 0 & 0 & 0 & 0 & 0 & 0 & 0 & 0 & 0 & 0 & 0 & 0 & 0 & 0 & 0 \\
\hline
\end{tabular}


TABLE A1 (Continued)

\begin{tabular}{|c|c|c|c|c|c|c|c|c|c|c|c|c|c|c|c|c|c|}
\hline & Y19 & Y20 & Y21 & Y22 & Y23 & Y24 & Y25 & Y26 & Y27 & PRIV & G0VT & I & Mros & Mrow & Xros & Xrow & Total \\
\hline$\overline{Y 1}$ & 0 & 0 & -3 & 0 & 0 & 0 & 0 & -218 & -23 & -795 & 0 & -12 & 975 & 354 & -77 & -49 & 0 \\
\hline Y2 & 0 & 0 & 0 & 0 & 0 & 0 & 0 & 0 & 0 & 0 & 0 & 0 & 36 & 18 & 0 & 0 & 0 \\
\hline Y3 & 0 & 0 & 0 & 0 & 0 & 0 & 0 & 0 & 0 & 0 & 0 & 0 & 0 & 1047 & 0 & 0 & 0 \\
\hline Y4 & -1 & -2 & -139 & 0 & 0 & 0 & 0 & -5 & 0 & -1 & 0 & 0 & 154 & 76 & -10 & -10 & 0 \\
\hline Y5 & -2 & -12 & 0 & 0 & -289 & -14 & -3 & -11 & -4 & -572 & 0 & -28 & 137 & 52 & -245 & -303 & 0 \\
\hline Y6 & -1 & -2 & 0 & 0 & 0 & 0 & 0 & -7 & -2 & -217 & 0 & 0 & 0 & 184 & -150 & 125 & \\
\hline Y7 & -17 & -16 & -4 & -14 & 0 & 0 & 0 & -112 & -37 & -224 & 0 & 0 & 363 & 0 & 0 & 0 & \\
\hline Y8 & -12 & -11 & -21 & 0 & -5 & 0 & 0 & -59 & -46 & -175 & 0 & 0 & 0 & 0 & -83 & 0 & \\
\hline Y9 & 0 & 0 & 0 & 0 & 0 & 0 & 0 & -640 & -65 & -2165 & 0 & -45 & 1842 & 407 & -860 & -253 & 0 \\
\hline Y10 & -4 & -10 & -3 & 0 & -1 & 0 & 0 & -18 & -14 & -815 & 0 & -3 & 716 & 191 & -107 & -96 & 0 \\
\hline Y11 & -22 & -156 & -78 & 0 & -23 & 0 & 0 & -380 & -115 & -199 & 0 & -23 & 389 & 322 & -999 & -315 & 0 \\
\hline Y12 & -123 & -29 & -40 & 0 & -21 & 0 & 0 & -75 & -16 & -100 & 0 & -25 & 125 & 137 & -750 & -739 & 0 \\
\hline Y13 & -54 & -61 & -36 & -1 & -5 & -1 & -1 & -95 & -100 & -320 & 0 & -1 & 1275 & 472 & -740 & -310 & 0 \\
\hline Y14 & -442 & -581 & -227 & -1 & -2 & 0 & 0 & -15 & -2 & 0 & 0 & -26 & 2058 & 1366 & -1059 & -1737 & 0 \\
\hline Y15 & -267 & -86 & -866 & 0 & -3 & 0 & 0 & -4 & -2 & -2 & 0 & -438 & 515 & 178 & -1258 & -658 & 0 \\
\hline Y16 & 0 & 0 & -185 & 0 & -1 & 0 & 0 & 0 & 0 & 0 & 0 & 0 & 189 & 2 & -9 & -11 & 0 \\
\hline Y17 & -21 & -2 & -76 & 0 & 0 & 0 & 0 & -8 & -2 & -5 & 0 & 0 & 110 & 34 & -144 & -108 & 0 \\
\hline Y18 & -142 & -56 & -465 & -1 & -6 & 0 & 0 & -362 & -23 & -329 & 0 & -2583 & 1998 & 1666 & -2211 & -2407 & 0 \\
\hline Y19 & 2841 & -2 & 0 & -9 & -24 & -12 & -14 & -85 & 0 & -375 & 0 & -703 & 733 & 541 & -623 & -2230 & 0 \\
\hline Y20 & -136 & 2743 & -194 & -1 & -2 & 0 & 0 & -16 & -22 & -212 & 0 & -544 & 349 & 421 & -1189 & -901 & 0 \\
\hline Y21 & -6 & -9 & 6337 & -6 & -51 & 0 & & -1796 & -169 & -12 & 0 & -4159 & 0 & 0 & 0 & 0 & 0 \\
\hline Y22 & -6 & -5 & -3 & 111 & -5 & 0 & 0 & -26 & -11 & -46 & 0 & -2 & 55 & 0 & 0 & 0 & 0 \\
\hline Y23 & -56 & -79 & -175 & -5 & 2409 & -17 & -14 & -419 & -156 & -727 & 0 & -81 & 791 & 43 & -540 & -342 & 0 \\
\hline Y24 & -2 & 0 & 0 & 0 & -1 & 87 & 0 & -61 & -18 & -85 & 0 & 0 & 142 & 7 & -32 & -30 & 0 \\
\hline Y25 & -4 & -5 & -1 & 0 & -4 & 0 & 94 & -6 & -3 & -18 & 0 & -1 & 135 & 12 & -37 & -44 & 0 \\
\hline Y26 & -439 & -356 & -1497 & -12 & -487 & -9 & -13 & 16764 & -959 & -9463 & 0 & -573 & 2334 & 38 & -1841 & -330 & 0 \\
\hline Y27 & -44 & -5 & -16 & 0 & -16 & 0 & 0 & -72 & 6526 & -2063 & -4126 & -187 & 76 & 1 & -6 & -5 & 0 \\
\hline $\mathrm{L}$ & -455 & -586 & -1082 & -70 & -457 & -20 & -21 & -4033 & -3564 & 14130 & 0 & 0 & 0 & 0 & 0 & 0 & \\
\hline K & -409 & -506 & -832 & -40 & -850 & -8 & -22 & -6965 & -541 & 14717 & 0 & 0 & 0 & 0 & 0 & 0 & 0 \\
\hline TAXL & -128 & -174 & -310 & -21 & -156 & -8 & -6 & -1173 & -972 & 0 & 4053 & 0 & 0 & 0 & 0 & 0 & 0 \\
\hline SUBP & 17 & 14 & 6 & 70 & 17 & 2 & 0 & 84 & 391 & 0 & -717 & 0 & 0 & 0 & 0 & 0 & 0 \\
\hline TAXP & -65 & -6 & -90 & 0 & -17 & 0 & 0 & -187 & -51 & 0 & 954 & 0 & 0 & 0 & 0 & 0 & 0 \\
\hline TAXC & 0 & 0 & 0 & 0 & 0 & 0 & 0 & 0 & & -1926 & 1926 & 0 & 0 & 0 & 0 & 0 & 0 \\
\hline TAXLS & 0 & 0 & 0 & 0 & 0 & 0 & 0 & 0 & 0 & 2090 & -2090 & 0 & 0 & 0 & 0 & 0 & 0 \\
\hline Savings & 0 & 0 & 0 & 0 & 0 & 0 & 0 & 0 & & -9434 & - 0 & 9434 & 0 & 0 & 0 & 0 & 0 \\
\hline Tradebal & 0 & 0 & 0 & 0 & 0 & 0 & 0 & 0 & 0 & -604 & 0 & 0 & -15675 & -75691 & 2970 & 10878 & 0 \\
\hline tal & 0 & 0 & 0 & 0 & 0 & 0 & 0 & 0 & 0 & 0 & 0 & 0 & 0 & 0 & 0 & 0 & \\
\hline
\end{tabular}

Source: From Input-Output Tables 1999 Basque Country (EUSTAT, 2000). 
TABLE A2

Sectoral Production, Consumption and $\mathrm{CO}_{2}$ Emissions

\begin{tabular}{|c|c|c|c|c|c|c|c|c|}
\hline & \multirow{2}{*}{$\begin{array}{l}\text { Sector Numbers } \\
\text { and Description }\end{array}$} & \multirow{2}{*}{ A-84 Code } & \multicolumn{2}{|c|}{ Producion } & \multicolumn{2}{|c|}{ Consumption } & \multicolumn{2}{|c|}{ Emissions } \\
\hline & & & mln Euro & (share) & mln Euro & (share) & $\mathrm{Gg} \mathrm{CO}_{2}$ & (share) \\
\hline Y1 & Agriculture & $1-4$ & 676 & $(1,1 \%)$ & 764 & $(3,6 \%)$ & 539 & $(3,8 \%)$ \\
\hline Y2 & Coal Extraction & 5 & 0 & $(0,0 \%)$ & 0 & $(0,0 \%)$ & 0 & $(0,0 \%)$ \\
\hline Y3 & $\begin{array}{l}\text { Oil and Natural Gas } \\
\text { Extraction }\end{array}$ & 6 & 0 & $(0,0 \%)$ & 0 & $(0,0 \%)$ & 0 & $(0,0 \%)$ \\
\hline Y4 & Other Product Extraction & $7-9$ & 152 & $(0,3 \%)$ & 1 & $(0,0 \%)$ & 52 & $(0,4 \%)$ \\
\hline Y5 & Oil Refineries Products & 23 & 1449 & $(2,4 \%)$ & 270 & $(1,3 \%)$ & 176 & $(1,2 \%)$ \\
\hline Y6 & Gas Natural Products & 23 & 184 & $(0,3 \%)$ & 240 & $(0,9 \%)$ & 25 & $(0,2 \%)$ \\
\hline Y7 & Electricity & 52 & 672 & $(1,1 \%)$ & 182 & $(0,9 \%)$ & 2995 & $(21,2 \%)$ \\
\hline Y8 & Energy Distribution & 53.54 & 570 & $(1,0 \%)$ & 154 & $(0,7 \%)$ & 52 & $(0,4 \%)$ \\
\hline Y9 & Food Industry & $10-16$ & 1846 & $(3,1 \%)$ & 2009 & $(9,5 \%)$ & 77 & $(0,5 \%)$ \\
\hline Y10 & $\begin{array}{l}\text { Clothes. leader and shoes } \\
\text { industry }\end{array}$ & $17-19$ & 186 & $(0,3 \%)$ & 699 & $(3,3 \%)$ & 30 & $(0,2 \%)$ \\
\hline Y11 & $\begin{array}{l}\text { Paper and Cardboard } \\
\text { Industry }\end{array}$ & $20-22$ & 1797 & $(3,0 \%)$ & 172 & $(0,8 \%)$ & 213 & $(1,5 \%)$ \\
\hline Y12 & Plastic Industry & 27.28 & 1847 & $(3,1 \%)$ & 84 & $(0,4 \%)$ & 168 & $(1,2 \%)$ \\
\hline Y13 & Chemic Industry & $24-26$ & 1033 & $(1,7 \%)$ & 270 & $(1,3 \%)$ & 94 & $(0,7 \%)$ \\
\hline Y14 & Iron and Steel Industry & $32-34$ & 2396 & $(4,0 \%)$ & 0 & $(0,0 \%)$ & 663 & $(4,7 \%)$ \\
\hline Y15 & No metallic Industry & $31.35-37$ & 3445 & $(5,8 \%)$ & 1 & $(0,0 \%)$ & 140 & $(1,0 \%)$ \\
\hline Y16 & Cement Industry & 30 & 87 & $(0,1 \%)$ & 0 & $(0,0 \%)$ & 161 & $(1,1 \%)$ \\
\hline Y17 & Glass Industry & 29 & 280 & $(0,5 \%)$ & 4 & $(0,0 \%)$ & 143 & $(1,0 \%)$ \\
\hline Y18 & Machines Industry & $39-45$ & 5309 & $(8,9 \%)$ & 263 & $(1,2 \%)$ & 132 & $(0,9 \%)$ \\
\hline Y19 & Transport machines Industry & $46-48$ & 2841 & $(4,7 \%)$ & 306 & $(1,4 \%)$ & 47 & $(0,3 \%)$ \\
\hline Y20 & Rest of industry & $38.49-51$ & 2743 & $(4,6 \%)$ & 169 & $(0,8 \%)$ & 222 & $(1,6 \%)$ \\
\hline Y21 & Construction & 55 & 6337 & $(10,6 \%)$ & 11 & $(0,1 \%)$ & 0 & $(0,0 \%)$ \\
\hline Y22 & Transport by train & 60 & 111 & $(0,2 \%)$ & 42 & $(0,2 \%)$ & 0 & $(0,0 \%)$ \\
\hline Y23 & Transport by road & 61.62 .65 & 2409 & $(4,0 \%)$ & 656 & $(3,1 \%)$ & 5029 & $(35,6 \%)$ \\
\hline Y24 & Transport by air & 64 & 87 & $(0,1 \%)$ & 70 & $(0,3 \%)$ & 244 & $(1,7 \%)$ \\
\hline Y25 & Transport by water & 63 & 94 & $(0,2 \%)$ & 16 & $(0,1 \%)$ & 52 & $(0,4 \%)$ \\
\hline Y26 & Commercial services & $\begin{array}{c}56-59 . \\
66-72 . \\
74.82 .83\end{array}$ & 16764 & $(28,0 \%)$ & 8655 & $(41,0 \%)$ & 305 & $(2,2 \%)$ \\
\hline \multirow[t]{3}{*}{ Y27 } & Non Commercial services & $73.75-81$ & 6526 & $(10,9 \%)$ & 6135 & $(29,0 \%)$ & 102 & $(0,7 \%)$ \\
\hline & Household & & & & & & 2590 & $(17,4 \%)$ \\
\hline & Total & & 59841 & $(100 \%)$ & 21173 & $(100 \%)$ & 14250 & $(100 \%)$ \\
\hline
\end{tabular}

Source: Calculated from the SAM. 
TABLE A4

Physical emission coefficients and contribution of fossil fuels in combustion

\begin{tabular}{lrrr}
\hline & Coal & Oil & Gas \\
\hline Ton $\mathrm{CO}_{2}$ Equiv./Ktep & 4,104 & 2,851 & 2,187 \\
Chemical Industry & $69 \%$ & $65 \%$ & $38 \%$ \\
Industry & - & $75 \%$ & -
\end{tabular}

Source: Eurostat 2005.

TABLE A5

Price of Energy (M€/Ktep)

\begin{tabular}{lrrrrc}
\hline & Crude & Coal & Oil & Gas & Electricity \\
\hline Producers & 0.108 & 0.105 & 0.265 & 0.219 & 0.763 \\
Consumers & - & - & 1.062 & 0.472 & 1.135 \\
\hline
\end{tabular}

Source: IEA 1998 and Eurostat 2005.

TABLE A6

Elasticities of Substitution on production, trade and consumption

\begin{tabular}{llcl}
\hline \multicolumn{1}{c}{ Elasticities } & \multicolumn{1}{c}{ Values } & Elasticities & Values \\
\hline \multirow{2}{*}{$\sigma_{j}^{K E L(1)}$} & 0.5 (Sect. 1-3, 5-8) & $\sigma^{E}$ & 0.3 \\
& 0.69 (Sect. 4, 9-21) & $\sigma^{E 1}$ & 0.5 \\
& 0.88 (Sect. 22-25) & $\sigma^{E 2}$ & 2 \\
\hline \multirow{3}{*}{$\sigma_{j}^{K L(2)}$} & 0.56 (Sect. 1) & $\sigma^{U}$ & 0.5 \\
& 1.12 (Sect. 2, 5, 7, 8) & $\sigma^{C}$ & 0.5 \\
& 1.26 (Sect. 3, 4, 6, 9-10, 26, 27) & $\sigma^{F}$ & 1 \\
& 1.40 (Sect. 21) & $\sigma^{G}$ & 1 \\
& 1.68 (Sect. (22-25) & $\sigma^{A}=\sigma^{T}$ & 3 \\
\hline
\end{tabular}

Source: Gomez et al. (2004) and (1) Kemfert \& Welsch (2000); (2) Hertel (1997). 